DOI: $10.34101 /$ actaagrar/2/3686

\title{
The examination of flesh firmness in different apple varieties
}

\author{
Mihály Orosz-Tóth - Sándorné Kincses \\ University of Debrecen, Faculty of Agricultural and Food Sciences and Environmental Management, Institute of Agricultural Chemistry and \\ Soil Science, Debrecen \\ otmisi@gmail.com
}

SUMMARY

Of the different physical features of fruits, one important quality feature is flesh hardness. This is an important parameter to be considered when selling fresh apples, for the manufacturing industry and when entering into storage. In our research, we examined 7 apple varieties, in 2016 and 2017, from the establishment of KITE Zrt. in Derecske and the Horticultural Experimentation Site of Pallag (Pallagi Kertészeti Kisérleti Telep). The plantations took place in accordance with intensive apple production. In both years, samples were collected at the time ripening of the given apple variety. Of the examined apple varieties, 5 of them are resistant to scab (Gaia, Isaaq, Modi, Smeralda, Fujion), 1 is not resistant (Golden Reinders) and 1 (Pinova) is moderately susceptible to scab. The scab resistant apple varieties were correlated to the non-resistant Golden Reinders. Flesh firmness was measured with a fruit penetrometer in each of the seven apple varieties. In the first year a two-month storage experiment was carried out, where the flash firmness after harvest, and after one-month and two-month storage was measured. The results were assessed with the help of the IBM SPSS Statistics 20 program. The goal is to compare the apple varieties based on their flesh firmness, in particular with regard to the resistant varieties.

The Isaaq 8.81-8.82 N/ $\mathrm{cm}^{2}$, the Modi $9.18-9.59 \mathrm{~N} / \mathrm{cm}^{2}$ and the Fujion 8.66-9.13 $\mathrm{N} / \mathrm{cm}^{2}$, all of which are scab resistant apple varieties, showed a significant initial flesh firmness. During storage, the Pinova apple variety flesh firmness changed the most favourably.

Keywords: flesh firmness, examination by penetrometer, storage

\section{INTRODUCTION}

Due to the favourable conditions for apple production, apple is the fruit produced on the largest area in Hungary. Amongst its several benefits, the most important one is that it can be stored for a long time and thus, it is available fresh for the consumers almost during the whole year. (Laczkovszki, 2012) Given the situation of the market, the apple producers also prefer the apple varieties suitable for long-term storage. For instance, Jonathan, Gala, Pinova, Gloster, Jonagold, and Idared are popular Of the farmers in Hungary. (Inántsy and Balázs, 2004). One important aspect in variety selection is disease control; one of the most efficient and environmentally sound way of which is the production of resistant varieties (Jha et al., 2009).

Of the examined 7 apple varieties, one is fully (Golden Reinders), one is medium susceptible to (Pinova) and 5 are resistant (Gaia, Isaaq, Modí, Smeralda, Fujion) to venturia scab, the causative agent of which is Venturia inequalis (Cooke, 2000). The fungus is mainly infectious during the rainier periods, after which the symptoms appear on the leaves, flowers, and fruits of the apple tree. After the infection, spotes (germinated conidium) that hold appear on the apple itself; they become humid, start cracking, and later saprobiontic bacteria and fungi appears on the apple causing decay (Bowen et al., 2011). There are three solutions recommended for protection against the fungus (Venturia inequalis) planting apple varieties resistant to scab venturia; the provision of appropriate chemical treatment (also necessary for resistant varieties in small amount) or the collection and burning of leaves in the fall to minimise the infection (Ficzek and Tóth, 2013).
Flesh firmness is an important characteristic of fruit quality; the penetrometer method can be used to measure flesh firmness. The concept of firmness means the resistance of a certain material against the penetrometer head forced into the examined test material (Felföldi, 2007). In general, firmness is characterised by force and deformation (Fekete et al., 2002). Fruit penetrometer is forced into the duct part of the apple flesh and resistance is measured. According to Tukey and Young (1942), the cortex and the stele, which constitute the duct, can be found under the epidermis. This is a part of the apple flesh which is mainly consists of parenchyma cells (Smith, 1950). The middle lamella, which is rich in pectins, is situated between the parenchyma cell walls. The cell walls and the middle lamellas are basically a crosslinked structure (Kállay, 2010), which greatly influences flesh firmness.

The main reason of flesh softening is that structure of the cell wall changes and the water soluble pectin increases in the tissues. This process is caused by the activity of the pectinesterase and polygalactrunase enzymes (Kállay, 2010). The pectat-lias enzyme is also part of the process; it is responsible for the fission of the deesterificated $\mathrm{Ca}^{2+}$ bonded pectin chains. Besides the above mentioned pectic enzymes, the softening of the apple flesh is also influenced by autocatalytic ethylene synthesis, climacteric respiration (Fidler, 1973), as well as starch content dissolution.

The aim of this research is to compare the firmness of the seven apple varieties, looking for connections between scab resistance and flesh firmness. 


\section{MATERIALS AND METHODS}

In the experiment, in 2016 and 2017, we examined the flesh firmness of apples from two plantations. One of the plantations is the horticultural establishment of the KITE Zrt. in Debrecen; two apple varieties were collected from there. In the first year, a two month storage experiment was carried out where the flesh firmness was measured in the picking/initial period, as well as after one and after two months. The storage temperature was $16-17{ }^{\circ} \mathrm{C}$. In 2017 , firmness was measured only in the picking period.

\section{Area, apple varieties, plantation data}

The horticultural establishment of KITE Zrt. in Debrecen has 5 apple varieties: Gaia, Isaaq, Modí,
Smeralda and Fujion. These varieties were bred in Italy and all of them are resistant to scab. Their picking time is in accordance with the order they have been listed. The apple trees were planted in 2014, with support equipment, hail net and dropping irrigation equipment. The intensive plantation is shaped on a M.9 rootstock in the spindle-shaped crown form. Both chemical and mechanical processes are applied on the plantation. Plant protection and nutrition supplement are carried out in accordance with the integrated principles. Trees are yearly pruned at the end of winter. The physical variety of the soil is sand, its $\mathrm{pH}$ is slightly acid, lacking in $\mathrm{CaCO}_{3}$. Its $\mathrm{N}$ supply is medium, $\mathrm{P}$ and $\mathrm{K}$ supply is quite good. (Gonda and Apáti, 2013). The important physical and chemical features of the soil are shown in Table 1.

KITE Zrt. establishment in Derecske - soil data

\begin{tabular}{ccccccccc}
\hline Level depth $[\mathrm{cm}]$ & $\mathrm{K}_{\mathrm{A}}$ & $\begin{array}{c}\mathrm{Humus} \\
{[\mathrm{m} / \mathrm{m} \%]}\end{array}$ & $\begin{array}{c}\mathrm{P}_{2} \mathrm{O}_{5} \\
{\left[\mathrm{mg} \mathrm{kg}^{-1}\right]}\end{array}$ & $\begin{array}{c}\mathrm{K}_{2} \mathrm{O} \\
{\left[\mathrm{mg} \mathrm{kg}^{-1}\right]}\end{array}$ & $\begin{array}{c}\mathrm{CaCO}_{3} \\
{[\mathrm{~m} / \mathrm{m} \%]}\end{array}$ & $\mathrm{y}_{1}$ & $\mathrm{pH}_{\mathrm{KCl}}$ & $\mathrm{pH}_{\mathrm{H} 2 \mathrm{O}}$ \\
\hline $0-20$ & 25 & 0.9 & 281 & 330 & $<0.1$ & 8.8 & 5.50 & 6.51 \\
$20-40$ & 25 & 0.9 & 325 & 308 & $<0.1$ & 10.3 & 5.26 & 6.27 \\
$40-60$ & 25 & 0.7 & 85 & 187 & $<0.1$ & 12.0 & 4.45 & 5.63 \\
\hline
\end{tabular}

Two apple varieties were picked from the Horticultural Experimentation Site of Pallag: Golden Reinders and Pinova. Golden Reinders is from the Netherlands and the mutant of the Golden Delicious. This variety is bigger in size and can be stored for a longer time, but also susceptible to mildew, scab and other fungus diseases. The Pinova variety was bred from crossing Clivia and Golden Delicious in the Drezda Pillnitz (Germany). It can be harvested at the end of September, the beginning of October and can be stored until April. The winter and spring frosts do not harm it, it is medium susceptible to scab, however, barely susceptible to other diseases. (Gonda and Fülep, 2011; Tóth, 2013) The two apple varieties were planted in 2008, with support equipment and dropping irrigation equipment in sand soil. The intensive plantation was shaped on a M.26 rootstock in the spindle-shaped crown form. Thinning of the apple trees used in the experiment was carried out manually. Plant protection and soil application are carried out in accordance with the integrated principles. According to soil data, humus and nitrogen content is considered good; the $\mathrm{Ca}$ content is higher compared to the plantation in Derecske; as a result of that, the soil is slightly alkaline. 
According to the data shown in the table, in both plantations the year of 2016 was rainier, while the year of 2017 was drier.

\section{Sampling}

In both years, samples were collected at the ripening time of the given variety. In accordance with the representative sampling, 4-5 kg were picked three times from each variety; that is why, flesh firmness examination was repeated 3 times with every apple variety.

\section{Penetrometer testing}

Flesh firmness was measured with a fruit penetrometer. This device is equipped with a cylindrical shaped measuring head, which exerts pressure on the fruit by pushing the hand. The apple skin was removed thinly, in a $1.5-2 \mathrm{~cm}$ wide stripe. The head was forced into the apple flesh in 3 different points: close to the stalk, on the side of the fruit and on the lower part of the fruit. There is an indicator line on the head of the device that shows how far to enter the fruit. With the help of the strength sensor the device is able to select the necessary strength to enter. The results were given in kilopond which were converted to $\mathrm{N} / \mathrm{cm}^{2}$. The bigger the exerted force is on the fruit, the higher the extent of tissue destruction becomes. The harder the fruit flesh is, the bigger force is necessary to enter.

\section{Statistics}

The measured data was recorded in the Excel program. For One-Factor Analysis of Variance, the IBM SPSS Statistics 20 program was used.

\section{RESULTS AND DISCUSSION}

On Figure 1 flesh firmness of the apple varieties at picking time is shown, in 2016.

Figure 1: Flesh firmness of apple varieties at harvest time (2016)

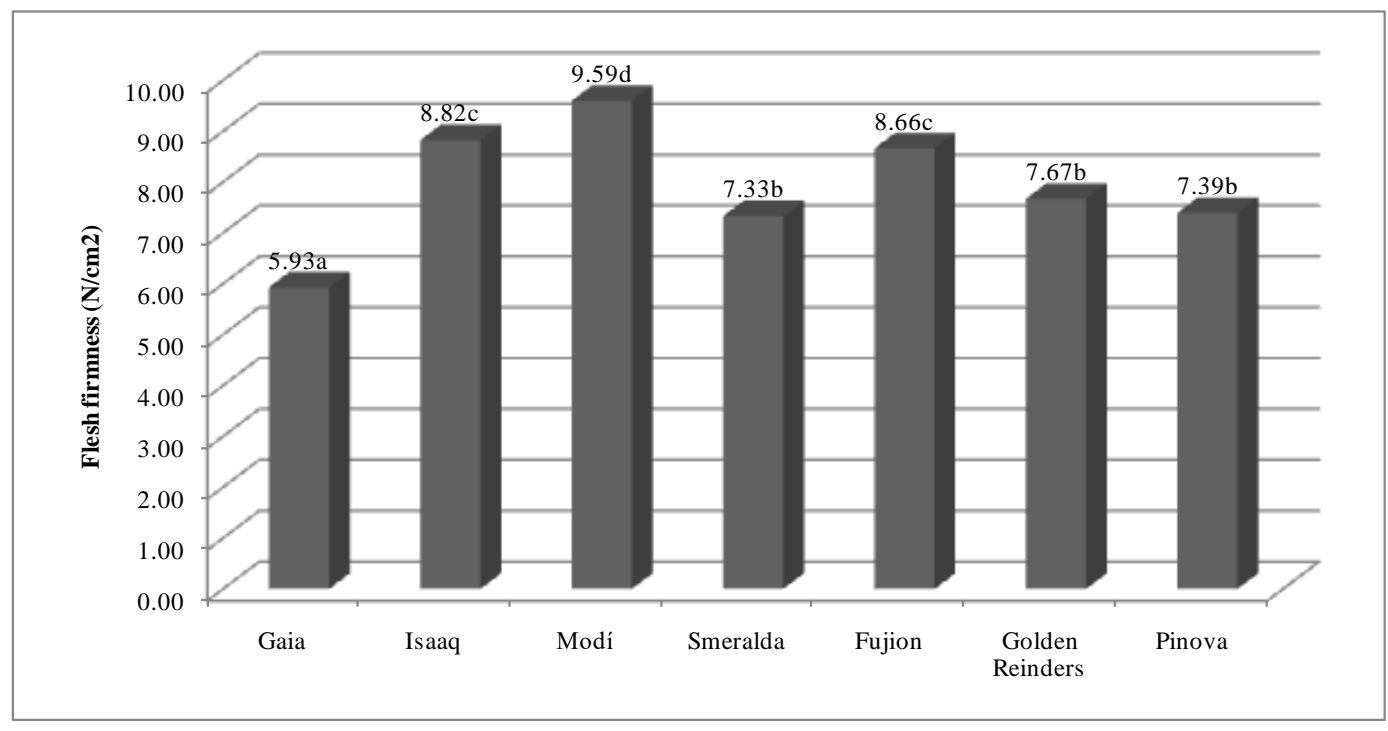

As shown in figure, statistically verified, the seven apple varieties can be divided into four groups. Gaia has the lowest measured value of $5.93 \mathrm{~N} / \mathrm{cm}^{2}$. Modí has the highest flesh firmness, which forms a separate group, similarly to Gaia. Two more groups can be significantly distinguished based on flesh firmness: one consists of Smeralda, Golden Reinders and Pinova varieties, while Isaaq and Fujion belongs to another group. Over all, the scab resistant apple varieties (Gaia, Isaaq, Modí, Smeralda, Fujion) have different flesh firmness.

Figure 2 shows the results of the flesh firmness examinations in 2017. Here, similarly to the diagram before, the apple varieties can be divided into four groups based on the measured parameter. The flesh firmness of Gaia increased greatly compared to the last year (28.24\%). (This probably due to the fact that the mildew attacked the Gaia apple variety so the representative sampling could not be done.) This year the Golden Reinders variety had the lowest flesh firmness $\left(6.91 \mathrm{~N} / \mathrm{cm}^{2}\right)$. The Isaaq, Modí and Fujion varieties have the best flesh firmness results in 2017 as well, which, statistically verified, belong to one group.

Figure 3 show the results of the storage experiment in the first year (2016). In general, there was a decrease in all seven apple varieties, during the first and the second measurement. After one-month storage, the firmness of the apples changed drastically in contrast to the results at picking time. The two varieties that changed the most, are the Fujion and Golden Reinders, which showed a 38 and $41.1 \%$ decrease compared to the initial measurements. It can be partly explained by the fact that they were stored in high temperature, $16-17^{\circ} \mathrm{C}$, which greatly speeded up the softening process. The results of Gaia and Golden 
Reinders were already below the critical firmness of $5.00 \mathrm{~N} / \mathrm{cm}^{2}$ at the second measurement. The changing of the flesh firmness slowed down to the last, 3 . measurement. Statistically verified, it can be stated that in case of every apple variety, the softening process slows down after time. At the last measuring, besides the Gaia and Golden Reinders, Smeralda and Fujion were also under the critical flesh firmness. Pinova had the lowest degree of flesh softening. At the last measuring, the extent of softening in this variety was $13 \%$ and stayed above the critical flesh firmness with $1.43 \mathrm{~N} / \mathrm{cm}^{2}$.

Figure 2: Flesh firmness of apple varieties at harvest time (2017)

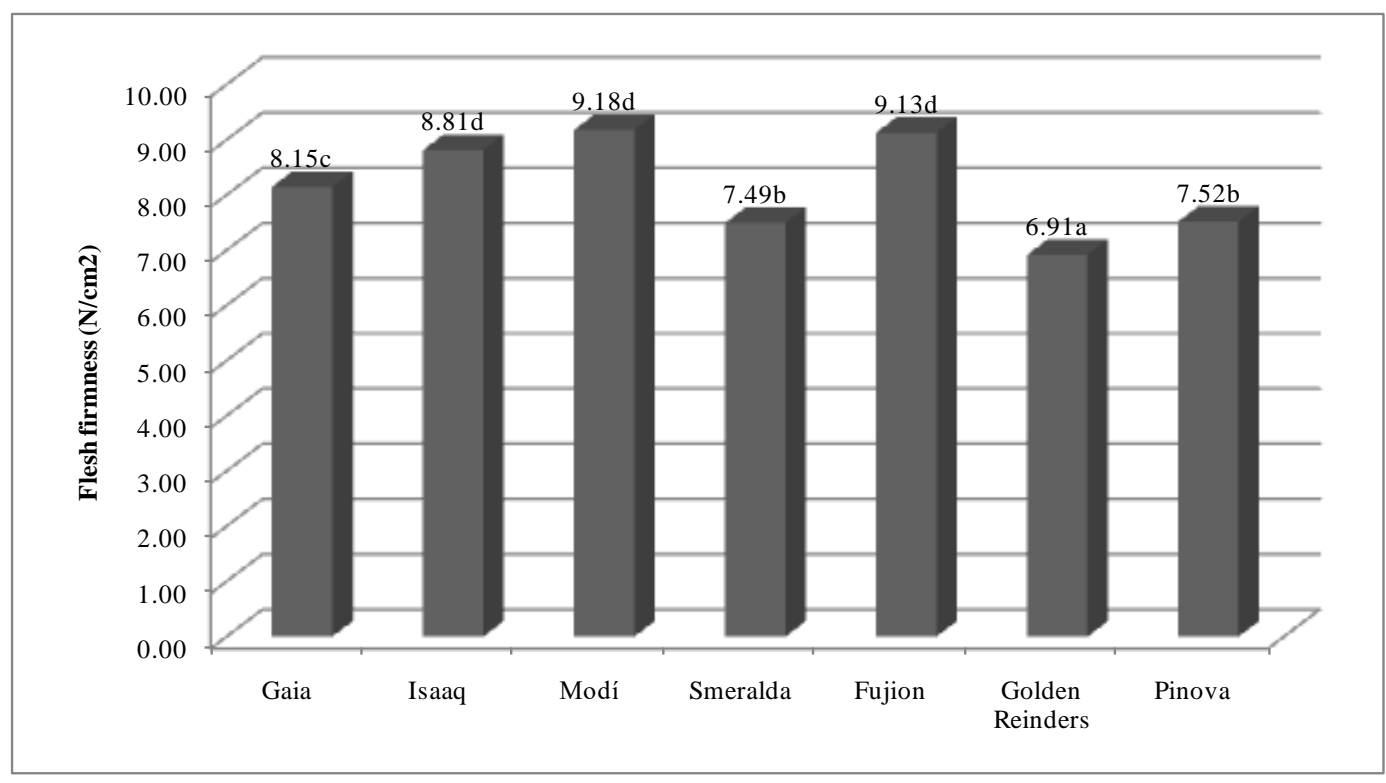

Figure 3: Storage experiment results of apple flesh firmness (2016)

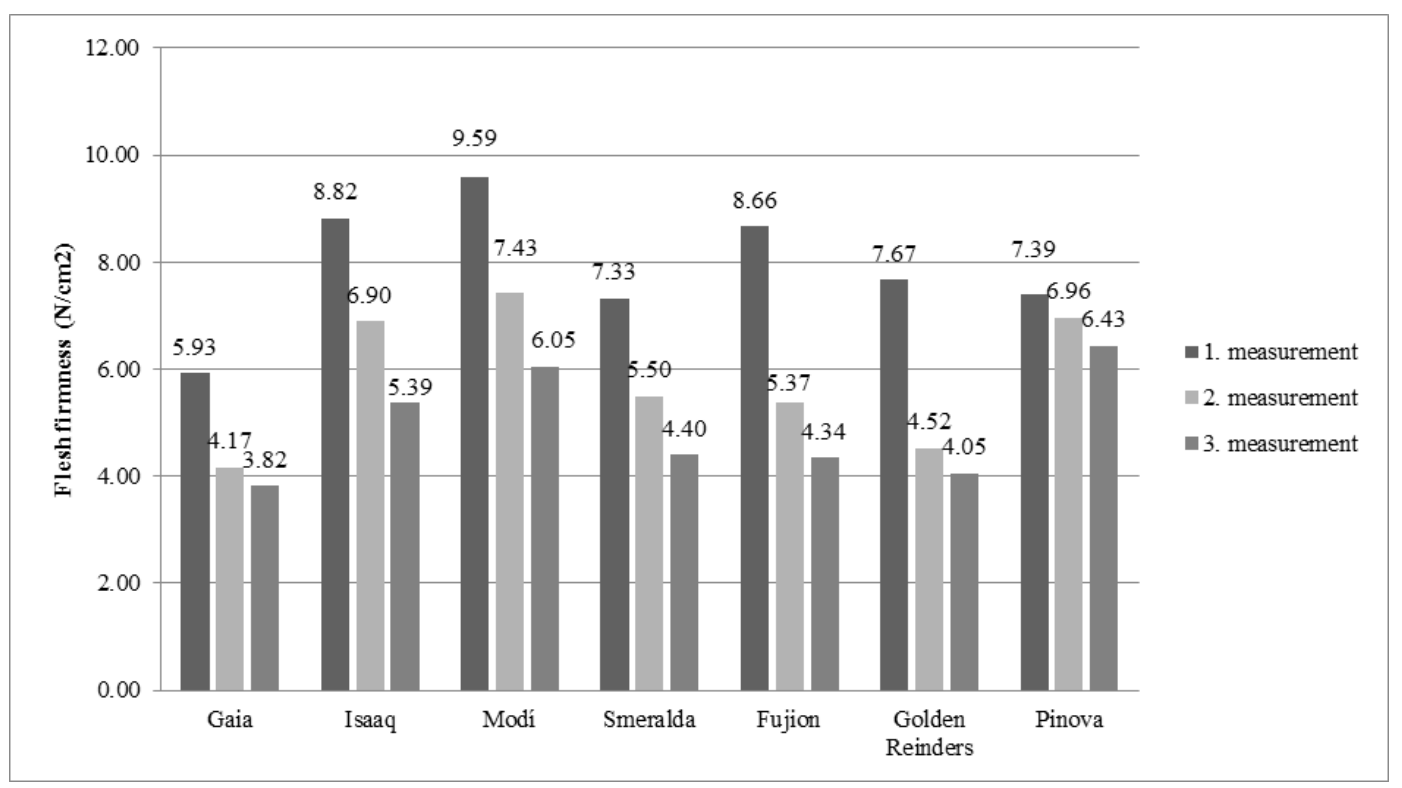

SzD $\%$ : Gaia- 0.241, Isaaq-0.313, Modí-0.307, Smeralda-0.270, Fujion-0.406, Golden Reinders-0.243, Pinova-0.095

\section{CONCLUSIONS}

Except for the Gaia apple variety (disease), based on the results, the flesh firmness of the examined apple varieties in harvest time 2016 changed only slightly till 2017. As a result, it can be concluded that this examined parameter is determined most importantly by genetic features. The scab resistant 
apple varieties have a more compact and solid flesh tissue, which was also displayed in the results based on the first measurements. Comparing the scab resistant apple varieties with the nonresistant varieties (Golden Reinders), or the apple varieties medium susceptible to the mentioned disease, it was shown that the firmness of the resistant varieties show higher numbers at harvest time.

In the storage experiment, the firmness of all 7 apple varieties was continuously decreasing during the 2 months. (which was a significant change). The softening of the apple tissue for the second measurement was generally $26.54 \%$, which only changed to $15.15 \%$ for the third measurement. Based on these results, it can be stated that the extent of the softening process gradually slows down. Of the 7 apple varieties, based on firmness, Pinova is the most suitable for storage; even though it did not show the highest results at harvest, but it had the lowest softening during two months storage.

\section{REFERENCES}

Cooke, M. S.-Evans, M. D.-Herbert, K. E.-Lunec, J. (2000) Urinary 8-oxo-2'-deoxyguanosine-source, significance and supplements. Free Radic Res. 32(5): 381-397.

Fekete, A.-Felföldi, J.-Borsa, B. (2002): Kertészeti termények mechanikai és minőségi jellemzői- Mezőgazdasági Gépesítési Tanulmányok- Az FVM Műszaki Intézet közleménye, Gödöllő, XLI. évfolyam, 2. szám

Ferföldi, J. (2007): Minőségvizsgálatok és élelmiszer-biztonság. In: Barta, J. (szerk.): A gyümölcsfeldolgozás technológiái. Mezőgazda Kiadó, Budapest. 248-258.

Ficzek, G.-Tóth, M. (2013): A gyümölcsök beltartalmi anyagai. In: Tóth, M. (szerk.): Magyarország kultúrflórája- Az alma. Agroinform Kiadó, Budapest. 190.

Fidler, J. C. (1973): Basic physiology (In Fidler et al.: The biology of apple and pear storage. Commonwealth Agricultural Bureau (C.A. B.) 5.

Gonda, I.-Apáti, F. (2013): Versenyképes almatermesztés. Szaktudás Kiadó Ház Zrt., Budapest. 31., 134-144.

Gonda, I.-Fülep, I. (2011): Az almatermesztés technológiája. Debreceni Egyetem Agrár- és Gazdaságtudományok Centruma, Kutatási és Fejlesztési Intézet, Gonda István Betéti Társaság, F. N. Fruit. Kft. Budapest. 32-33.

Inántsy, F.-Balázs, K. (2004): Integrált növénytermesztés- ALMA. Agroinform Kiadó, Budapest. 58-65., 69
Jha, G.-Thakur, K.-Thakur, P. (2009). The Venturia Apple Pathosystem: Pathogenicity Mechanisms and Plant Defense Responses. Journal of Biomedicine and Biotechnology, 2009, 680160. http://doi.org/10.1155/2009/680160

Bowen, J. K.-Mesarich, C. H.-Bus, V. G. M.-Beresford, R. M.Plummer, K. M.-Templeton, M. D. (2011): Venturia inaequalis: the causal agent of apple scab: MOLECULAR PLANT PATHOLOGY 12(2), 105-122. DOI: 10.1111/J.1364-3703.2010.00656.X

Kállay, T. (2010): Az almatárolás biológiai alapjai. Mezőgazda Kiadó, Budapest. 7-9.

Laczkovszki, Cs. (2012): Gyümölcstermesztés. Magyar Agrárkamara, Budapest. 1-238. p. ISBN 9786155307065

Smith, W. H. (1950): Cell multiplication and cell enlargement in the development of the flesh of the apple fruit. Annals of Botany N. S. (14) 53. 23-38.

Tóth, M. (2013): Az alma fajtái. In: Tóth, M. (szerk.): Magyarország kultúrflórája- Az alma. Agroinform Kiadó, Budapest. 312 .

Tukey, H. B.-Young, J. O. (1942): Gross morphology and histology of the developing fruit of the apple. Botanical Gazette 104. p. $1-25$. 
